JOAL, (JOURNAL, (DF APPIIEI) IINGUIS'IICS ANI) II'TIRA'TURE)

Vol. 5 No.1, 2020

ISSN (print): 2502-7816; ISSN (online): 2503-524X

Available online at https:/ / ejournal.unib.ac.id/index.php/joall/index

doi: $\underline{\text { http: / / dx.doi.org/10.33369/joall.v5i1.8005 }}$

\title{
ANALYSIS OF STUDENTS' UNDERSTANDING OF IDIOMATIC EXPRESSIONS AND ITS USE IN THEIR ESSAY: A CASE STUDY
}

\author{
Dalilah Fathma'; Nurlela²; Muhammad Yusuf ${ }^{3}$ \\ Universitas Sumatera Utara ${ }^{1,2,3}$ \\ Corresponding email: laafathma@gmail.com
}

\begin{abstract}
This research aims to find out the types of idiomatic expressions which are used by the students in their English essay and to describe on how far is their understanding of idiomatic expressions. In conducting this research, the writer applies qualitative approach by using content analysis to observe the types of idioms found in the students' essays and doing an interview sessions in order to assess their understanding of idiomatic expressions. Based on the analysis, it is found that there are two types of idiomatic expressions found in the students' essays. Both types are consisted of each one idiom for one student, those are A cup of tea categorized as Compound and Drop your jaw categorized as Verb + object/complement (and/or adverbial). Whilst, the results of their understanding of idiomatic expressions through interview session show that 6 of 7 were not able in passing the first facet of Six Facets of Understanding which is Explanation and categorized as the students do not understand about idiom, while 1 of 7 students could pass all facets and categorized as the only student who understands about idioms. The results show that actually the 4th semester of English Department students of Universitas Sumatera Utaraare not that familiar with idioms since five of seven of them did not use idiom in their essays and six of seven of them could not pass the facets of understanding.
\end{abstract}

Keywords: idiomatic expression, students' understanding, essay

\section{INTRODUCTION}

Idiomatic expressions is a common word or phrase which means something different from its literal meaning, but can be understood because of their popular use. Carter as cited in Syarfuni (2014) defines idioms as special combinations with restricted forms and meanings that cannot be deduced from the literal meanings of the words which make them up. 
Almost all of English natives use idioms in their daily conversation (mostly informal) and media as idioms have already existed even in 1550s. Of course, idioms consisted of phrases, clause, and even sentence, which make them easy to be used and found as well. When idioms are used correctly, it can amplify messages in a way that draws readers in and helps to awaken their senses. Thus, the meaning of the idiomatic expressions needs to be recognized and understood correctly based on its context.

Miscommunication and misconception about English idioms happen frequently whether it is spoken or written. Hence, lots of English youtubers such as Learn English with Lucy, ETJ English, linguamarina, and many more then made some videos about English idioms in order to explain and clarify the real meaning of the English idioms. Besides, learning idioms is also such a good way in order to know the natives' cultures through their language. The important of being able to understand the idiomatic expressions is also shown by the amount of researchers who conducted the research about idiomatic expressions, such as Zahra Fotovatnia and Mehdi Goudarzi (2014), Emilija Funtek (2015), Rana Abid Thyab (2016), and many more.

According to Emilija (2015), in her research, she also showed that in general the ESL (English Second Learners) were indeed difficult in recognizing the idioms because of its different meaning. She believed that one factor which caused it is because the teachers did not devote enough attention and time to teach idioms to their students. Comparing to the research conducted by the writers, the writers used the English Department students with higher achievement who were genuinely majoring English in their study as the subject, while Emilija used ESL as the subject.

English Department students who learn English should at least be more aware in interpreting the meaning of idiomatic expressions and realising its existence in English conversation whether it is spoken or written. Other than that, the sudents who have higher GPA should at least more understand about English idioms. In fact, even those who have higher GPA are still not able in interpreting the meaning yet realising its existence, it is shown by the results where only two of the subjects research who used idioms in their essays and only one student who is considered understood according to the writer's research.

In Universitas Sumatera Utara, the 2nd semester of English department students, were once given some phrases and idiom and asked to make a sentence from each phrases and idiom. From preliminary observation, it was discovered that most of them were difficult in recognizing, making, interpreting, and understanding the idiom since most of them misplaced the idiom in making a sentence. As one of the idioms, " $a$ piece of cake" should be used as it means easy or not difficult, for example I can pass the examination, the test was just a piece of cake. In this sentence, it 
practically tells that the test was just that easy to be passed. But, instead of making a correct sentence, the students put the idiom oppositely as if it is not an idiom, for example I do not bring much food for lunch, just a piece of cake, which means s/he brought nothing but a piece of cake for lunch.

In this research, the writers attempt to analyse the very basic thing in idiomatic expressions itself, that is to find out the types of idioms in students' writing and how the English department students of Universitas Sumatera Utara understand the English idioms.

\section{METHODS}

\section{Subject of the Research}

In conducting this research, the writer chose the second year (2017) of English Department students who get a Cum Laude GPA $(\geq 3.51)$ as the subjects. Based on the data in Direktori Mahasiswa USU, from the total of 128 students, there are only 14 students who pass the criteria of writers' research subject where it is considered as population. In this research, the subjects are all of the population; those are 14 English Department students of Universitas Sumatera Utara with Cum Laude GPA ( $\geq 3.51)$ who are now in the $4^{\text {th }}$ semester.

However, $i$ the process of conducting the research, the writers found problems in contacting the students. Half of the subjects are not responding monthly and some are not willing to be the subject of the research. Despite of the things happened, the writers then took that as a rejection and focuses on analyzing the other half of the subjects, where there were 7 students in total. The list of the students is shown in table 1.

Table: 1 List of the students with Cum Laude GPA $(\geq 3,51)$

\begin{tabular}{lccc}
\hline \multicolumn{1}{r}{ Name (Initial) } & Gender & Class & GPA \\
\hline AORR & M & B & 3,51613 \\
DP & M & A & 3,54688 \\
DIYP & F & A & 3,58065 \\
HM & M & B & 3,6129 \\
JB & F & A & 3,625 \\
SNAW & F & A & 3,73438 \\
SH & F & B & 3,8871 \\
\hline
\end{tabular}

Source: Direktori Mahasiswa - Universitas Sumatera Utara

\section{Source of Data and Data}

The source of data is the students' English essays that will be analysed and the students itself who will be interviewed in order to get the data. The data of this research are all types of idiomatic expressions found in the students' English essays based on the theory proposed by Michael McCarthy and Felicity O'Dell (2010) and the interview sheets. The types of idiomatic 
expressions are verb + object/complement (and/or adverbial) $(\mathrm{V}+\mathrm{O})$, prepositional phrases (PP), compound (C), simile/simili (as + adjective + as, or like + noun) $(S)$, binomial (word + and + word) $(B)$. trinomial (word + word + and + word) $(\mathrm{T})$, and whole clause and sentence (WCS).

\section{Method of Data Collection}

According to Miles, Huberman, and Saldana (2014:46), data collection is divided into 4 types; those are observation, questionnaire, interview, and study the document. In this research, the writer choose interview and study the document in case of getting the answer of the problems. Step in collecting the data are as follows :

- Contacting the $4^{\text {th }}$ semester of English Department students of Universitas Sumatera Utara with Cum Laude GPA (14 students).

- Asking for their English essay. In this part, the writer will ask them to make an essay about their holiday in Microsoft Office Word with the 500-word-maximum and 300-word-minimum.

- Collecting the essays.

- Doing a face-to-face interview with each student to assess their understanding of idiomatic expressions. In this part, the questions that will be given are based on the question pattern in Understanding by Design (1998) book by Wiggin and McTighe. The questions are shown below :

Table: 2 The Questions List of Six Facets of Understanding

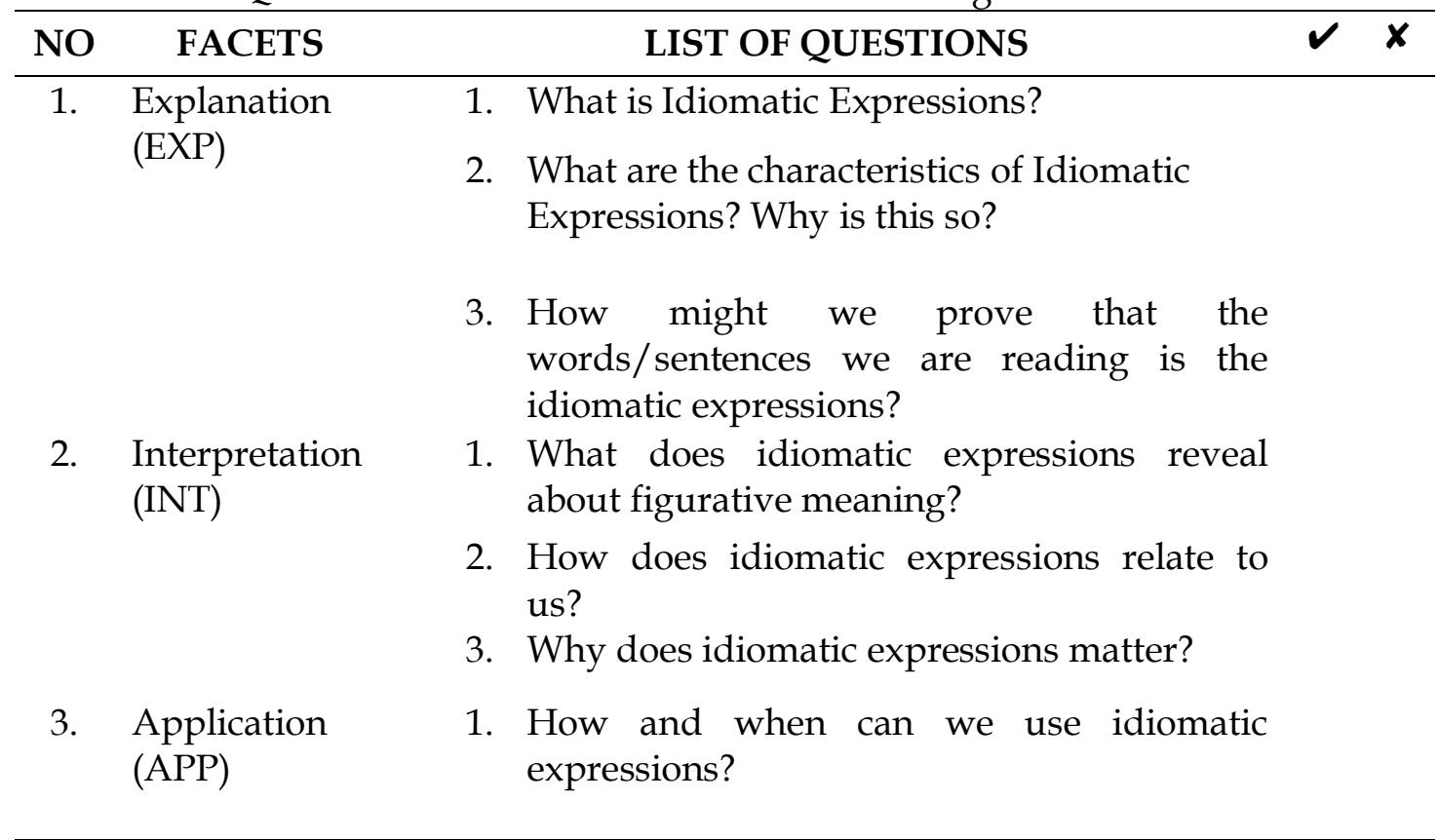




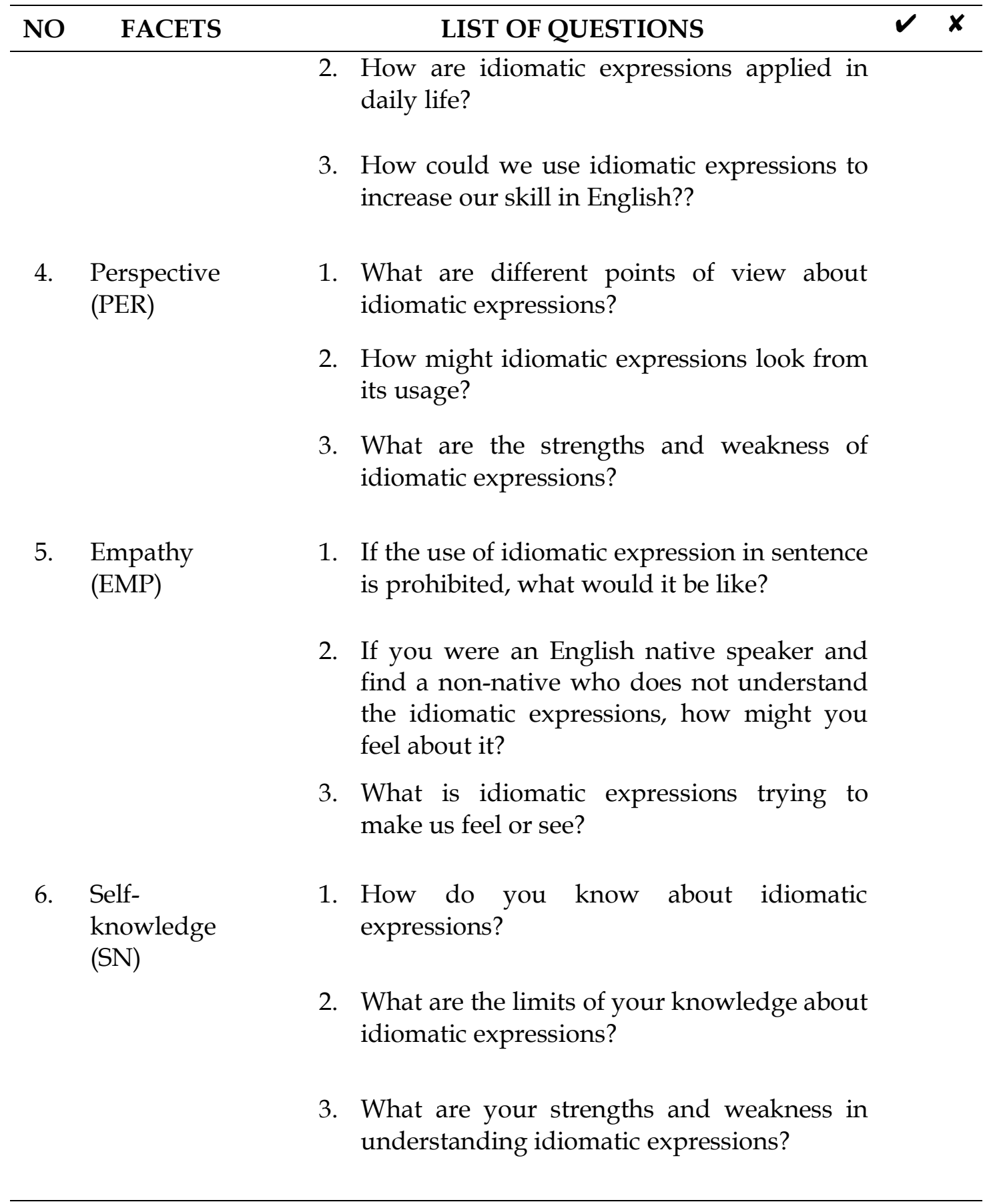

- Recording the interview session and noting the answers of each interviewee in the interview sheets.

- Collecting the data. 


\section{Technique of Data Analysis}

The data of this research are analysed based on interactive models proposed by Miles, Huberman, and Saldana (2014) with four phases of data analysis. The four phases of data analysis are data collection, data condensation, data display, and conclusion: drawing/verification.

\section{Data Condensation}

In this research, the data selected are all types of idiomatic expressions found in English Department students' essays and the interview notes from the interview session. This research focuses on analysing the $4^{\text {th }}$ semester of English Department students of University of Sumatera Utara understands of idiomatic expressions through their English essays and interview session. In analysing their essays, the writers only focuses on Michael McCarthy and Felicity O'Dell theory about 7 types of idiomatic expressions. In abstraction part, the writer tries to summarize the core, processes, and statements that need to be maintained. Then, the data in this research are further simplified and transformed in various ways, such as through rigorous selection, by summary or short description, and transforming the data into a broader pattern.

\section{Data Display}

Data display should be presented in tables, charts, networks, and other graphical formats. In this research, the data is presented in the form of table and descriptive text as follows:

Table: 3 The Data Display of Idioms types Found in the Students' Essay

\section{(Initial Name of the Students)} (Title of the Essay)

\begin{tabular}{|c|c|c|c|c|c|c|c|}
\hline No. & $\mathrm{V}+\mathrm{O}$ & $\mathbf{P P}$ & $\mathrm{C}$ & $S$ & B & $T$ & WCS \\
\hline 1. & $\begin{array}{l}\text { Kill two } \\
\text { birds } \\
\text { with } \\
\text { one } \\
\text { stone }\end{array}$ & $\begin{array}{l}\text { In the } \\
\text { blink } \\
\text { of an } \\
\text { eye }\end{array}$ & $\begin{array}{l}\text { A bone of } \\
\text { contention }\end{array}$ & $\begin{array}{l}\text { As } \\
\text { dry as } \\
\text { bone }\end{array}$ & $\begin{array}{l}\text { Rough } \\
\text { and } \\
\text { ready }\end{array}$ & $\begin{array}{l}\text { Cool, } \\
\text { calm, and } \\
\text { collected }\end{array}$ & $\begin{array}{l}\text { To cut } \\
\text { long } \\
\text { story } \\
\text { short }\end{array}$ \\
\hline
\end{tabular}

2.

3.

TOTAL

Table: 4 The Data Display of Final Data of Idioms Types Found in Students' Essays

\begin{tabular}{cccccccccc}
\hline No. & $\begin{array}{c}\text { Initial of } \\
\text { Student }\end{array}$ & $\mathbf{V}+\mathbf{O}$ & $\mathbf{P P}$ & $\mathbf{C}$ & $\mathbf{S}$ & $\mathbf{B}$ & $\mathbf{T}$ & WCS & TOTAL \\
\hline 1. & AORR & 12 & 2 & 11 & 5 & 3 & 2 & 23 & 58 \\
2. & DP & & & & & & & &
\end{tabular}




\begin{tabular}{clllllllll}
\hline No. & $\begin{array}{c}\text { Initial of } \\
\text { Student }\end{array}$ & V + O & PP & C & S & B & T & WCS & TOTAL \\
\hline 3. & DIYP & & & & & & & \\
4. & HM & & & & & & & \\
5. & JB & & & & & & & \\
6. & SNAW & & & & & & & \\
7. & SH & & & & & & & \\
\hline TOTAL & & & & & & & \\
\hline
\end{tabular}

Table: 5 The Data Display of Students' Interview Results

\begin{tabular}{|c|c|c|c|c|c|c|c|c|}
\hline No. & $\begin{array}{c}\text { Initial of } \\
\text { Student }\end{array}$ & EXP & INT & APP & PER & EMP & SN & RESULTS \\
\hline 1. & AORR & $\checkmark$ & $\checkmark$ & $\checkmark$ & $x$ & - & - & $\mathrm{APP}$ \\
\hline 2. & DP & $x$ & - & - & - & - & - & $x$ \\
\hline 3. & DIYP & $\checkmark$ & $x$ & - & - & - & - & EXP \\
\hline 4. & $\mathrm{HM}$ & $\checkmark$ & $\checkmark$ & $\checkmark$ & $\checkmark$ & - & - & PER \\
\hline 5. & JB & & & & & & & \\
\hline 6. & SNAW & & & & & & & \\
\hline 7. & $\mathrm{SH}$ & & & & & & & \\
\hline TOTAI & & & & & & & & \\
\hline
\end{tabular}

\section{Conclusion: Drawing/Verification}

From the start of data collection, the qualitative analysis interprets what things mean by noting patterns, explanations, casual flows, and proposition. In this research, however, the writer did the data condensation which is in the forms of students' essays and interview sheets. The steps of analysing the data are as follows:

1. Reading the students' essays.

2. Identifying and analysing the 7 types of each idiomatic expression based on the theory proposed by Michael McCarthy and Felicity O'Dell (2010).

3. Grouping each type of idiomatic expressions to where it belongs in the form of table.

4. Making a table of types of idiomatic expressions used by the students.

5. Reading the interview notes of each student.

6. Analysing the interview notes of the students based on the theory proposed by Grant Wiggin and Jay McTighe (1998)

7. Making conclusion.

\section{Instruments}

In this research, the instruments that were used were the writing forms and interview sheets. The writing forms were given to the students in order to 
make the essay, while the interview sheets were used by the writers in order to assess their understanding of idiomatic expressions.

\section{Data Analysis Procedures}

This research focuses on analysing the types of idiomatic expressions based on the theory proposed by Michael McCarthy and Felicity O'Dell (2010) found in the 4th semester of English Department students of University of Sumatera Utara's essays and to assess their understanding of idiomatic expressions through Six Facets of Understanding by the theory proposed by Grant Wiggins and Jay McTighe (1998).

\section{RESULTS}

\section{Idiomatic Expressions Found in the Students' Essays}

Having analysed the types of idiomatic expressions found in the students' essays, there are 2 types found in the students essay with total 2 idioms, those are verb + object/complement (and/or adverbial) and compound idiom. The result can be seen in the table below.

Table 6: The Data of Final Data of Idioms Types Found in Students' Essays

\begin{tabular}{clcccccccc}
\hline No. & Initial of Student & V + O & PP & C & S & B & T & WCS & TOTAL \\
\hline 1. & AORR & - & - & - & - & - & - & - & - \\
2. & DP & - & - & 1 & - & - & - & - & 1 \\
3. & DIYP & - & - & - & - & - & - & - & \\
4. & HM & - & - & - & - & - & - & - & \\
5. & JB & - & - & - & - & - & - & - & \\
6. & SNAW & - & - & - & - & - & - & - & \\
7. & SH & 1 & - & - & - & - & - & - & 1 \\
\hline TOTAL & & & & & & & 2
\end{tabular}

Based on the analysis of the students' essays, there are 2 types of idioms found in their essays. The data can be seen below.

Table 7: Data of DP

(DP)

(Singapore Trip)

\begin{tabular}{cccccccc}
\hline No. & V + O & PP & C & S & B & T & WCS \\
\hline 1. & - & - & A cup of tea & - & - & - & - \\
\hline TOTAL & & 1 & & & \\
\hline
\end{tabular}

Table 8: Data of SH

(SH)

(Bitten by a Horse by Itsana Negara Malaysia)

\begin{tabular}{cccccccc}
\hline No. & V + O & PP & C & S & B & T & WCS \\
\hline 1. & Drop your jaw & - & - & - & - & - & - \\
\hline TOTAL & 1 & & & & & & \\
\hline
\end{tabular}


In both essays of DP and $\mathrm{SH}$, the writers found two types of idiomatix expressions according to Michael McCarthy and Felicity O'Dell (2010), the first idiom was found in DP's essay, that is 'A cup of tea' formed by the words 'a', 'cup', 'of', 'tea', where the combination of two or more words is also known as compound. If it is translated literally, of course it will give a meaning of a cup filled with tea. But, when someone says 'It is not my cup of tea' or 'That is not our cup of tea' some non-natives might be confused. But, as it is a kind of idioms, a cup of tea means something that we prefer or not prefer.

The second idiom was found in SH's essay, that is 'Drop your jaw' formed by a verb 'drop' and 'your jaw' as the object. If it is translated literally, it will give a meaning of dropping our jaw and if it comes in a sentence like the student SH did, 'You will drop your jaw', of course it will become an ambiguity. Intrinsically, it is also impossible to physically drop our jaw when someone suddenly says 'You will drop your jaw after hearing this". In fact, drop your jaw is a kind of idiomatic expressions where it is used for saying that someone would be very surprised or shocked. While, the rest 5 students did not use idiomatic expressions in their essay.

In all five essays wrote by the rest of the subjects, the writer did not find any kinds of idiomatic expressions according to Michael McCarthy and Felicity O'Dell (2010), while the rest of the subjects are also the students who had the writers' criteria, where all of them were the students who had a Cum Laude GPA. In fact, there were so many types of idiom according to Michael and O'Dell which actually can be used in beautify a writing.

\section{Results of the Interviews Sessions based on Six Facets of Understanding}

Subsequently, according to the results of interview sessions, there was only 1 student who could pass all the facets and considered as the only student who had the understandingof idiomatic expressions, while the rest had failed at the first facet. The results of the interview sessions based on Six Facets of Understanding can be seen below.

Table: 9 The Data of Students' Interview Results

\begin{tabular}{|c|c|c|c|c|c|c|c|c|}
\hline No & $\begin{array}{c}\text { Initial of } \\
\text { Student }\end{array}$ & EXP & INT & APP & PER & EMP & SN & RESULTS \\
\hline 1. & AORR & $x$ & $x$ & $x$ & $x$ & $x$ & $x$ & $x$ \\
\hline 2. & $\mathrm{DP}$ & $x$ & $x$ & $x$ & $x$ & $x$ & $x$ & $x$ \\
\hline 3. & DIYP & $x$ & $x$ & $x$ & $x$ & $x$ & $x$ & $x$ \\
\hline 4. & HM & $x$ & $x$ & $x$ & $x$ & $x$ & $x$ & $x$ \\
\hline 5. & JB & $x$ & $x$ & $x$ & $x$ & $x$ & $x$ & $x$ \\
\hline 6. & SNAW & $\checkmark$ & $\checkmark$ & $\checkmark$ & $\checkmark$ & $\checkmark$ & $\boldsymbol{\nu}$ & Understood \\
\hline 7. & $\mathrm{SH}$ & $x$ & $x$ & $x$ & $x$ & $x$ & $x$ & $x$ \\
\hline
\end{tabular}


Based on the interview sessions the writer did with the total 7 students, the results show that there was only 1 student who could pass all of the six facets, while the other 6 students failed at the first facet. The interesting part of this research comes by the results that in fact 2 students of the first facet indeed used idiomatic expressions in their essay, but they were actually had no idea on what idiomatic expressions are. On the contrast, 1 student of the sixth facets who was categorized understood, did not use idiomatic expressions or applied what just she had told and thought about the important of idiomatic expressions, while she indeed had understanding of it.

\section{The First Facet of Understanding}

As a student of English Department, AORR, DP, DIYP, HM, JB, and, SH could not answer all 3 questions of the first facet, that is Explanation. At first, some of them ware nearly able in explaining what is idiomatic expressions, but when the writers asked to give the example, most of them gave up and ensured the writers that they had never heard about idiomatic expressions. DP, as one of the students with higher achivement, could not answer all 3 questions of the first facet. He seemed like he had never heard about idiomatic expressions at all. Along the 3 questions given, he just gave such 'pass' and 'I do not know' answers, showing that he really had no idea about idiomatic expressions, while in fact, he actually one of two students who put an idiom in his essays. DP could not move to the next facet since he could not answer all questions consisted in Explanation. He is then considered that he does not understand about idiomatic expressions even if he used it in his essay.

It went in parallel with $\mathrm{SH}$, the last student who could not pass the first facet of understanding. At first, when the writers gave the very first question, she thought a while as if she knew the answer, but right after that she then said 'pass'. In the process of interview sessions, $\mathrm{SH}$ seemed confused by the questions given about idiomatic expressions She just laughed and smiled showing her confusion of the questions. While in fact, she used the idioms in her essay.

\section{The Sixth Facet of Understanding}

SNAW is the only student who could pass all of the six facets of understanding. At the first facet, she indeed could not answer the first question by saying 'pass' directly. When the writers gave the second question in the first facet, she then could answer it a bit confidentlyand compatible to what the writers asked. At the second facet, Interpretation, SNAW could not answer the first question, but she had no problem with the second question given and could pass the second facet along with the 
examples. At the third facet, Application, again, she answered confidently, briefly, and of course correctly which then brought her to the next facet, Perspective. The first and second questions of the fourth facetcould not be answered at first, but it did not happen to the last question, she answered it well.

At the fifth and sixth facets, Empathy and Self-knowledge, she could answered both questions, right at the first questions given. As the result, she could finally pass all the questions consisted in all facets and considered as the student who understand about idiomatic expressions.

\section{DISCUSSION}

Native speakers love idioms, because they consider them to be an important part of their cultural heritage. Thus, non-native speakers of English or English learners should be aware of idiomatic expressions in order to be able to communicate effectively and sound more natural and native-like.

Based on the analysis of the research, it is indeed hard for the students in recognizing the idioms. It is proven by the total idioms found in the essays, which means there was less students who were familiar with the existence and the use of idioms, so that most of them did not use idioms in their essay. Other than that, the number of students who has understanding of idiomatic expressions was also so small.

The results of the previous research conducted by Emilija Funtek (2015), also show that non-native speakers or ESL (English Second Learners) were indeed difficult in recognizing the idioms because of its different meaning. She believed that one factor which caused it is because the teachers did not devote enough attention and time to teach idioms to their students. Comparing to the research conducted by the writer, more or less it has a same result where idioms are still difficult to be recognize and understood by the non-natives, where in this case the writer used the English Department students with higher achievement as the subject, while Emilija used ESL as the subject.

\section{CONCLUSION AND SUGGESTION}

Having been analysed, the data showed that there are two types of idiomatic expressions found in the students' essays based on the theory proposed by Michael McCarthy and Felicity O'Dell (2010). Both types are consisted of each one idiom for one student, those are A cup of tea categorized as Compound and Drop your jaw categorized as Verb + object/complement (and/or adverbial). Then, after assessing students' understanding of idiomatic expressions through the theory proposed by Grant Wiggin and Jay McTighe (1998), 6 of them were not able in even passing the first facet that is Explanation, while one student could pass a bit smoothly. 
In addition, the writer found that the student who uses idiomatic expressions in his/her essay might even did not realise what actually idiomatic expressions are or the words that $\mathrm{s} /$ he wrote in her/his essay is categorized as idioms. Yet, the student who did not use idiom in her/his essay cannot be directly categorized as the student who has no understanding of idiomatic expressions, that is why analysing both the writings and assessing the understanding are important to synchronize each other.

As the conclusion, the findings show that actually the 4th semester of English Department students of Universitas Sumatera Utarawith high achievement are not that familiar with idioms since 5 of 7 of them did not use idiom in their essays and 6 of 7 of them could not pass the facets of understanding.

\section{Suggestions}

In relation to the conclusion in advanced, the suggestion are presented as the followings:

For the English Department students, it is indeed necessary to learn and understand the idioms itself in order to have a good communicative way whether it is spoken or written. Besides, as the students who learn English language, learning the English idioms can avoid the non-natives from miscommunication in English conversation, yet it can enrich students' vocabulary and knowledge of English culture.

For the English Department lecturers, idiomatic expressions should be taught deeper whether in speaking, writing, or translation subject, due to increase their skill to become a native-like, to introduce the existence of idioms and its function, and of course to enrich their vocabulary, especially about idiomatic expressions.

For further research, this research can be analysed and discussed deeper in different subject. As the writer had found the results on English Department students with high achievement, it will be a great idea to conduct this kind of research to the students with low achievements so the results of both reserach can be compared.

\section{REFERENCES}

Aliaga, M., \& Gunderson, B. (2005). Interactive Statistics (3rd Edition). U.S.A: Prentice Hall.

Bobrow, S. A., \& Bell, S. M. (1973).On Catching on to Idiomatic Expressions. Memory and Cognition,1(3), 343-346.

Cacciari, C., \& Tabossi, P. (1988). The Comprehension of Idioms. Journal of Memory and Language, 27(6), 668-683. 
Cresswell, J. W. (2014). Research Design: Qualitative, Quantitative, and Mixed Methods Approaches. Lincoln: SAGE Publications.

De Caro, E. E. R. (2009). The Advantages snd Importance of Learning and Using Idioms in English. Cuadernos de Lingüística Hispánica, 14. 121136.

Elshamy, H. M. (2016). An Analysis of the Pragmatic Functions of Idiomatic Expressions in the Egyptian Novel 'Taxi'. Master thesis, The American University in Cairo.

Fitri. (2016). Translation Accuracy of English Idiomatic Expression into Indonesian in Big Hero 6 Film Subtitle. Undergraduate thesis, Universitas Islam Negeri Syarif Hidayatullah Jakarta.

Funtek, E. (2015). Idiom Comprehension in English As A Second Language. Undergraduate thesis, University of Rijeka.

Illah. (2016). Peraturan Menteri Ristek dan Dikti No. 44 Tahun 2015 Kopertis Wilayah III. Retrieved November 23, 2018, from kopertis3: kopertis3.or.id/v5/wp-content/uploads/Bu-Illah-SN-DIKTI-44-2015SOSIALISASI-APTISI.pdf

Mantyla, K. (2004). Idioms and Language Users: The Effect of The Characteristics of Idioms on Their Recognition and Interpretation by Native and Non-native Speakers of English. Dissertation, Universitiy of Jyväskylä.

McCarthy, M., \& O’Dell, F. (2010). English Idioms in Use. Cambridge: Cambridge University Press.

Miller, R. (2019). Gumberg Library. Research Instrument. Retrieved March 6, 2019, from http:/ / guides.library.duq.edu/researchinstruments

Syarfuni, S. (2014). An Analysis of English and Indonesian Idioms and Proverbs. Getsempena English Education Journal, 1(1), 27.

Thyab, R. A. (2016). The Necessity of Idiomatic Expressions to English Language Learners. International Journal of English and Literature, 7(7), 106-111.

Titone, D. A., \& Connine, C. M. (1994). Comprehension of Idiomatic Expressions: Effects of Predictability and Literality. Journal of Experimental Psychology: Learning, Memory, and Cognition, 20(5), 1126-1138.

Wiggins, G., \&McTighe, J. (1998). Understanding by Design. In Six Facets of Understanding (pp. 85-97). Association for Supervision and Curriculum Development.

Zahra Fotovatnia, M. G. (2014). Idiom Comprehension in English as a Foreign Language: Analysability in Focus. Procedia - Social and Behavioral Sciences, 98(1), 499-503. 